\title{
Analisis Kesalahan Mahasiswa PGSD pada Tugas Aljabar Sederhana Mata Kuliah Konsep Dasar Mapel Matematika SD
}

\section{Komang Sesara Ariyana}

Sekolah Tinggi Agama Hindu Negeri Mpu Kuturan Singaraja

sesaraariyana@gmail.com

DOI : $10.37329 /$ cetta.v3i2.448

\begin{tabular}{l}
\hline Keywords: \\
\hline Error Analysis; \\
Algebra; \\
Mathematics; \\
PGSD \\
\hline
\end{tabular}

Abstract
This study aimed to identify the errors of PGSD students on simple
algebra assignments on Basic Concept of Elementary Mathematics
Subject at STAHN Mpu Kuturan Singaraja. The subjects of this study
were Semester II PGSD students of STAHN Mpu Kuturan Singaraja
in the academic year 2019/2020 as many as 11 people. Errors in
mathematics in this study were divided into factual errors, procedural
errors, and conceptual errors. This type of research was a quantitative
descriptive study. The data collection method used was a test. The test
instrument used was a concept understanding test to be able to find
students' errors. A total of 20 items in the test were validated by two
experts with the Lawshe's CVR technique. The results showed that (1)
the general error rate of PGSD study program students on Simple
Algebra assignment on Basic Concept of Elementary Mathematics
Subject was 30.26\% in the low error category, (2) there was the highest
error of 43\% (error category moderate) and lowest 16\% (very low error
category), 3) factual errors ranged from 10\% - 20\% (very low
category), 4) procedural errors ranged from 7\% - 53\% (very low
category to medium category), and 5) conceptual errors ranged from
35\% - 65\% (low to high categories).

\begin{tabular}{l}
\hline Kata Kunci: \\
\hline Analisis \\
Kesalahan; \\
Aljabar; \\
Matematika; \\
PGSD \\
\hline
\end{tabular}

\begin{tabular}{l} 
Abstrak \\
\hline Penelitian ini bertujuan untuk mengidentifikasi kesalahan \\
mahasiswa PGSD pada tugas aljabar sederhana mata kuliah \\
Konsep Dasar Mapel Matematika SD di STAHN Mpu Kuturan \\
Singaraja. Subjek penelitian ini adalah mahasiswa PGSD \\
semester II STAHN Mpu Kuturan Singaraja pada tahun \\
akademik 2019/2020 sebanyak 11 orang. Kesalahan dalam \\
matematika dalam penelitian ini dibedakan menjadi kesalahan \\
faktual, kesalahan prosedural, dan kesalahan konseptual. Jenis \\
penelitian ini merupakan penelitian deskriptif kuantitatif. \\
Metode pengumpulan data yang digunakan adalah tes. \\
Instrumen tes digunakan adalah tes pemahaman konsep untuk \\
dapat menemukan kesalahan mahasiswa. Sebanyak 20 butir
\end{tabular}


soal pada tes telah dilakukan validasi isi oleh dua orang pakar dengan teknik CVR Lawshe. Hasil penelitian menunjukkan bahwa (1) tingkat kesalahan secara umum mahasiswa program studi PGSD pada tugas materi Aljabar Sederhana mata kuliah Konsep Dasar Mapel Matematika SD adalah sebesar 30,26\% yang berada pada kategori kesalahan rendah, (2) terdapat kesalahan tertinggi sebesar 43\% (kategori kesalahan sedang) dan terendah 16\% (kategori kesalahan sangat rendah), (3) kesalahan faktual berkisar antara 10\% - 20\% (kategori Sangat Rendah), (4) Kesalahan prosedural berkisar antara 7\% - 53\% (kategori sangat rendah s.d. kategori sedang), dan (5) kesalahan konseptual berkisar antara 35\% - 65\% (kategori rendah s.d. kategori tinggi).

\section{Pendahuluan}

Program Studi PGSD merupakan salah satu program studi di kampus Sekolah Tinggi Agama Hindu Negeri (STAHN) Mpu Kuturan Singaraja. Program studi ini mempersiapakan lulusan untuk menjadi guru sekolah dasar. Untuk menjadi guru sekolah dasar, para mahasiswa calon guru harus menguasai lima bidang studi yang penting, yaitu Matematika, IPA, IPS, Bahasa Indonesia, dan Pendidikan Kewarganegaraan. Di bidang matematika, mahasiswa PGSD STAHN Mpu Kuturan dibekali melalui mata kuliah matematika. Mata kuliah matematika tersebut antara lain Konsep Dasar Mapel Matematika SD, Mapel SD Matematika 1, Mapel SD Matematika 2, dan Strategi Pembelajaran Matematika SD. Keempat mata kuliah ini tersusun secara berurutan mulai dari mata kuliah Konsep Dasar Mapel Matematika SD pada semester II hingga mata kuliah Strategi Pembelajaran Matematika SD pada semester V. Ini artinya perkuliahan matematika pada suatu semester disusun dalam urutan yang mendukung perkuliahan matematika pada semester berikutnya. Sesuai dengan pendapat Dawkins (2018) bahwa "math is cumulative". Matematika adalah kumulatif. Dengan kata lain, sebagian besar kelas matematika dibangun berdasarkan pengalaman yang dipeoleh di kelas matematika sebelumnya, termasuk kelas matematika pada jenjang sekolah.

Di jenjang apa pun, baik sekolah maupun perguruan tinggi, peserta didik pasti pernah mengalami kesalahan dalam memahami konsep matematika. Kesalahan konsep matematika merupakan salah satu kesalahan yang dapat dilakukan oleh peserta didik. Menurut Bethany (2016), jenis kesalahan dalam matematika (math error) ada 3 (tiga), yaitu kesalahan kecerobohan (careless error), kesalahan konsep (conceptual error), dan kesalahan berhitung (computational error). Serupa dengan pendapat Bethany, menurut 
Brown, Skow, \& The IRIS Center (2016), kesalahan dalam matematika dibedakan menjadi kesalahan faktual (factual error), kesalahan prosedural (procedural error), dan kesalahan konseptual (conceptual error). Selain itu, Watson (dalam Sanwidi, 2018) mengklasifikasi kesalahan dalam mengerjakan soal, yaitu: (a) data tidak tepat (innappropriate data), (b) prosedur tidak tepat (inappropriate procedure), (c) data hilang (ommited data), (d) kesimpulan hilang (omitted conclusion), (e) konflik level respon (response level conflict), (f) manipulasi tidak langsung (undirected manipulation), (g) masalah hirarki keterampilan (skills hierarchy problem), dan (h) selain ke-7 kategori di atas (above other).

Menurut Lestian, Rejeki, \& Setyawan, (2016), dalam memecahkan masalah matematika, pengetahuan konseptual dan prosedural diperlukan. Terkait dengan materi yang akan diteliti, yakni aljabar sederhana, termasuk persamaan dan pertidaksamaan linear satu variabel, terdapat penelitian yang relevan. Karlina, Masi, \& Kodirun (2018) meneliti kesalahan dalam materi persamaan dan pertidaksamaan linear satu variabel pada siswa. Hasil yang diperoleh dalam penelitiannya adalah jenis kesalahan yang dilakukan siswa meliputi kesalahan fakta, konsep, prinsip, dan operasi. Malihatuddarojah, \& Prahmana (2019) meneliti kesalahan siswa dalam menyelesaikan permasalahan operasi hitung aljabar. Hasil penelitian menunjukkan bahwa siswa melakukan beberapa kesalahan dalam menyelesaikan permasalahan tentang operasi bentuk aljabar, seperti kesalahan pada variabel, kesalahan pada tanda negatif, kesalahan pada menyelesaikan bentuk persamaan aljabar, dan kesalahan pada pengoperasian bentuk aljabar.

Tidak tertutup kemungkinan peserta didik di jenjang perguruan tinggi juga mengalami kesalahan dalam matematika tersebut. Dari pengalaman peneliti sebagai dosen yang mengampu mata kuliah Konsep Dasar Mapel Matematika SD di program studi PGSD STAHN Mpu Kuturan Singaraja, pembelajaran pada mata kuliah ini telah menggunakan pendekatan konstruktivisme yang berpusat pada mahasiswa dan terlihat berjalan dengan baik. Akan tetapi, ketika mahasiswa dihadapkan pada soal matematika, khususnya tentang aljabar sederhana, termasuk Persamaan dan Pertidaksamaan Linear Satu Variabel, mereka masih mengalami kesalahan dalam menyelesaikan soal tersebut.

Kesalahan dalam matematika dapat berupa jenis-jenis kesalahan yang disebutkan di atas. Mengidentifikasi kesalahan mahasiswa PGSD dalam matematika sangat penting, sebab mahasiswa harus siap menjadi guru matematika di sekolah dasar dengan segala kasus kesalahan siswa dalam matematika yang mungkin akan terjadi ketika 
benar-benar menjadi guru. Untuk dapat menganalisis kesalahan siswanya nanti, mahasiswa PGSD harus benar-benar paham akan kesalahan (error) yang telah dilakukan.

Berdasarkan hal tersebut, peneliti tertarik untuk melakukan penelitian yang lebih mendalam mengenai kesalahan yang dilakukan oleh mahasiswa PGSD pada mata kuliah Konsep Dasar Mapel Matematika SD. Kesalahan yang diteliti berdasarkan dari jenis faktual, konseptual, dan prosedural, mengingat bahwa apabila mengacu pada Taksonomi Bloom Revisi (Anderson \& Krathwohl, 2015), ketiga jenis kesalahan tersebut berkaitan dengan jenis-jenis pengetahuan tersebut, yakni pengetahuan faktual, pengetahuan konseptual, dan pengetahuan prosedural. Oleh karena itu, peneliti mengangkat penelitian yang bertujuan untuk (1) mendeskripsikan kesalahan secara umum mahasiswa program studi PGSD pada materi Aljabar Sederhana mata kuliah Konsep Dasar Mapel Matematika SD, dan (2) mendeskripsikan kesalahan mahasiswa PGSD pada materi Aljabar Sederhana mata kuliah Konsep Dasar Mapel Matematika SD berdasarkan jenis kesalahan faktual, konseptual, dan prosedural.

\section{Metode}

Jenis penelitian ini adalah penelitian deskriptif kuantitatif. Dalam penelitian ini, metode kuantitatif berperan untuk memperoleh data kuantitatif yang terukur yang bersifat deskriptif. Penelitian ini dilaksanakan di kampus Sekolah Tinggi Agama Hindu Negeri Mpu Kuturan Singaraja. Subjek penelitian dalam penelitian ini adalah seluruh mahasiswa program studi PGSD Kelas IIB di STAHN Mpu Kuturan Singaraja pada tahun akademik 2019/2020 sebanyak 11 orang. Variabel dalam penelitian ini hanya 1 (satu), yaitu kesalahan pada materi aljabar Sederhana mata kuliah Konsep Dasar Mapel Matematika SD. Kesalahan yang terjadi dapat berupa kesalahan faktual, kesalahan prosedural, dan kesalahan konseptual.

Metode pengumpulan data yang digunakan dalam penelitian ini adalah metode tes. Maka instrumen penelitiannya adalah tes. Tes yang dimaksud adalah tugas materi Aljabar Sederhana pada mata kuliah Konsep Dasar Mapel Matematika SD. Materi Aljabar Sederhana dibagi menjadi 3 (tiga) submateri, yaitu pengertian aljabar dan operasinya, persamaan linear satu variabel, dan pertidaksamaan linear satu variabel. Tugas yang dimaksud berisi 20 butir soal. Pengujian validitas isi secara statistik dapat dilakukan dengan menggunakan formula yang diusulkan oleh Lawshe (1975, dalam Shultz, Whitney, \& Zickar, 2013) yang dikenal dengan rasio validitas isi atau content 
validity ratio (CVR). Analisis data diarahkan untuk menjawab rumusan masalah deskriptif pada penelitian ini. Hasil penelitian kuantitatif ini berupa persentase.

\section{Hasil dan Pembahasan}

Hasil penelitian dianalisis berdasarkan kesalahan secara umum dan kesalahan berdasarkan jenisnya. Grafik 1 dan Grafik 2 berikut ini adalah diagram yang menunjukkan persentase kesalahan per butir soal dan persentase kesalahan per responden berturut-turut.

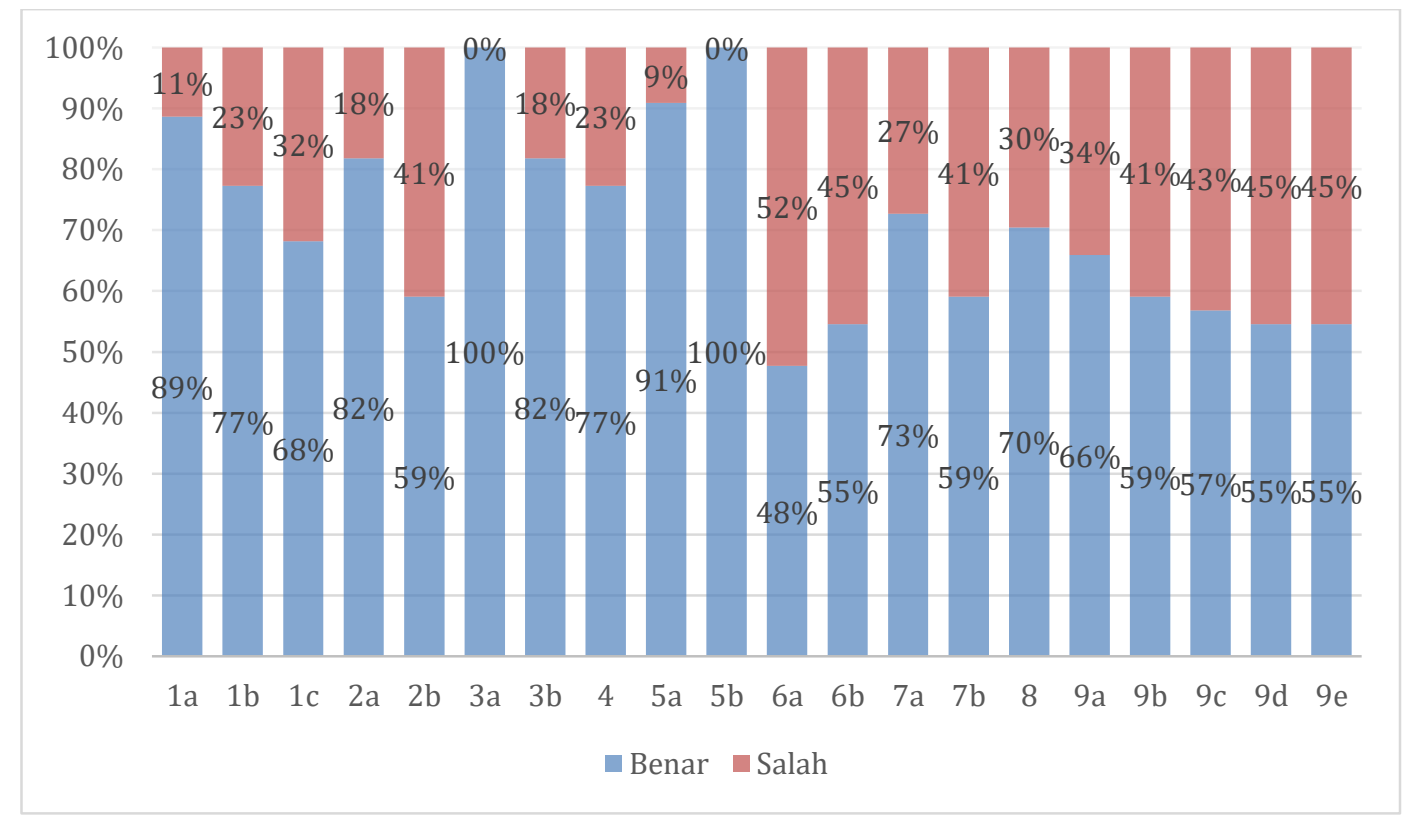

Grafik 1. Persentase Kesalahan per Butir Soal

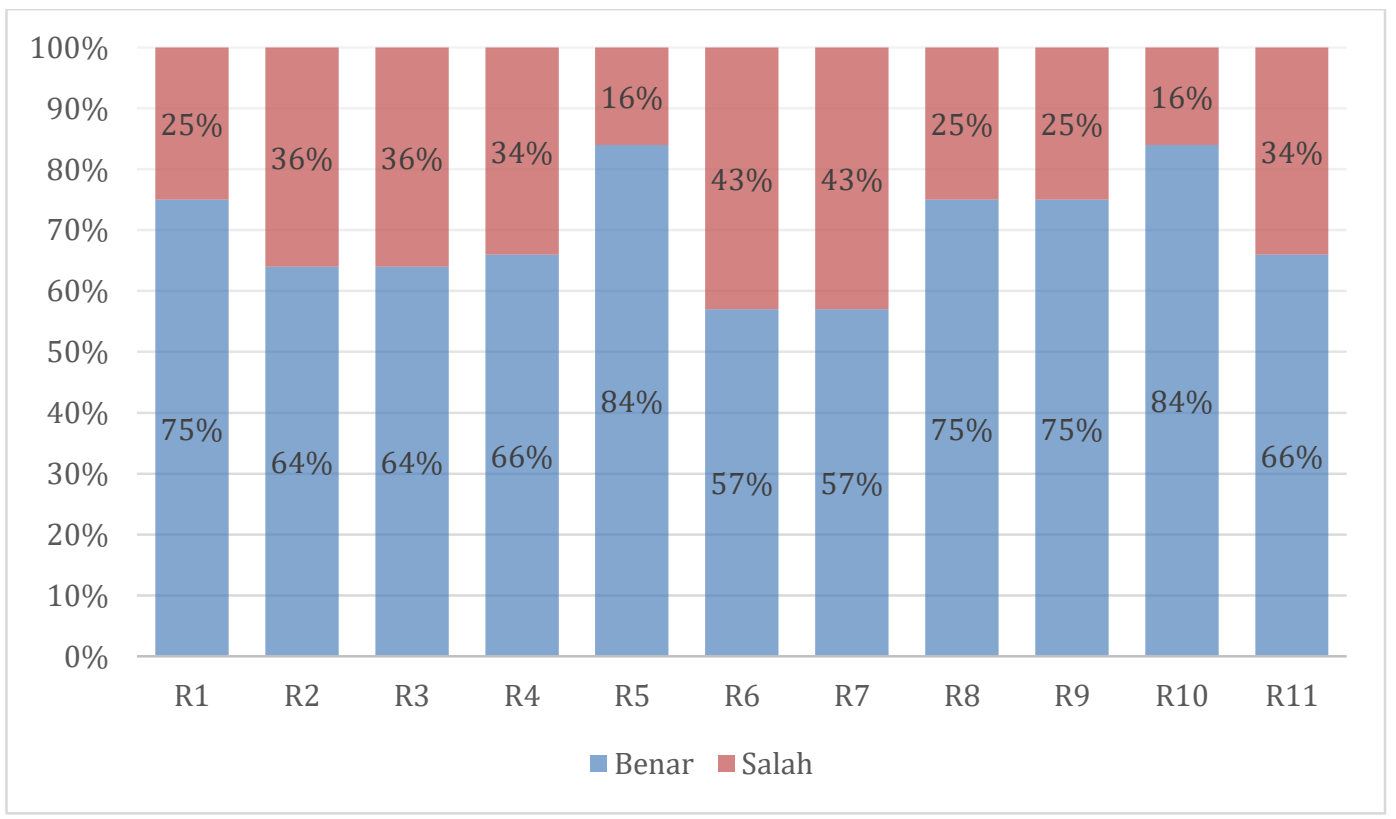

Grafik 2 Persentase Kesalahan per Responden 
Untuk mengetahui kesalahan berdasarkan jenis-jenis kesalahannya, yakni kesalahan faktual, kesalahan konseptual, dan kesalahan prosedural, dapat dilihat pada Grafik 3 dan Grafik 4 di bawah ini. Grafik 3 menunjukkan persentase kesalahan per butir soal berdasarkan jenis kesalahan dan Grafik 4 menunjukkan persentase kesalahan per responden berdasarkan jenis kesalahan.

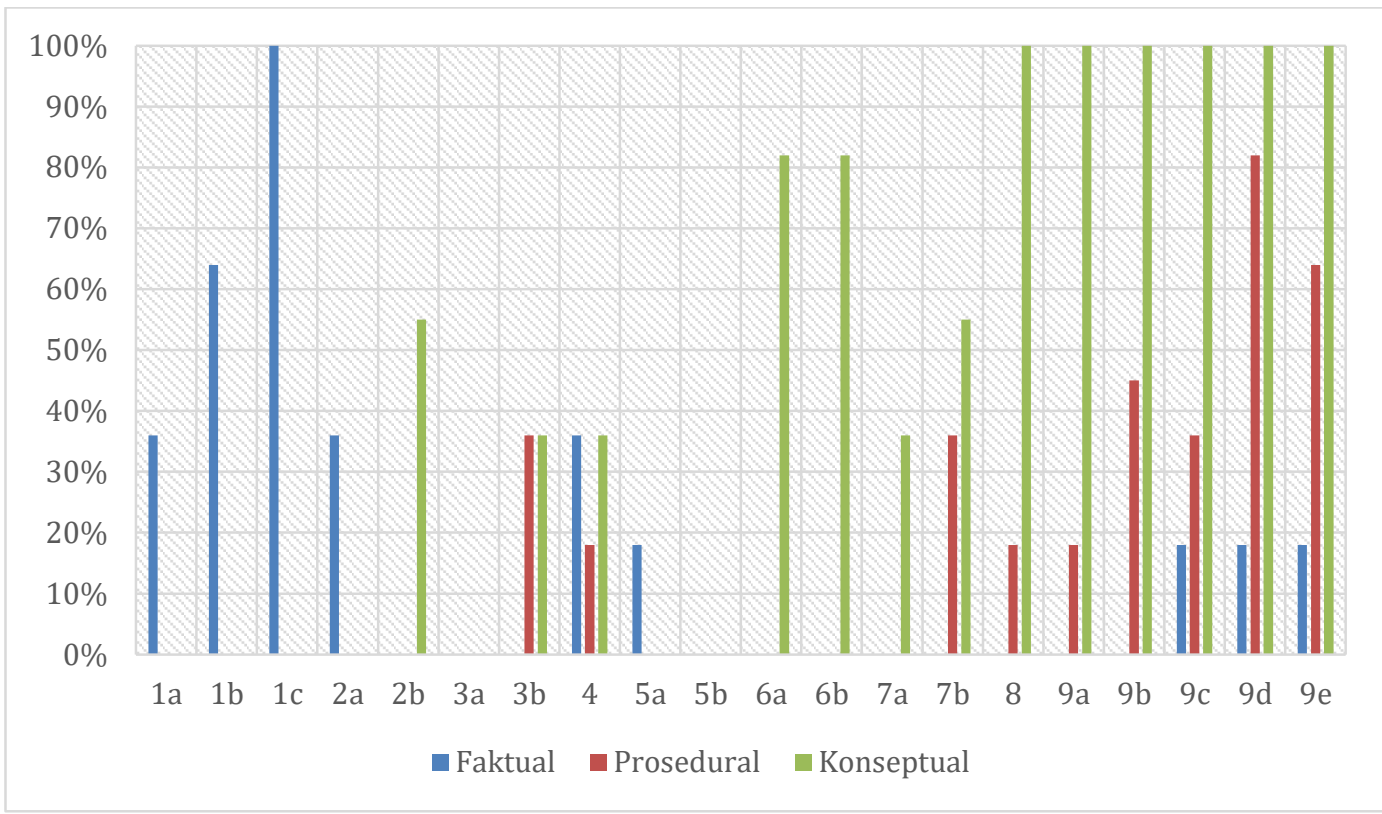

Grafik 3. Persentase Kesalahan per Butir Soal Berdasarkan Jenis Kesalahan

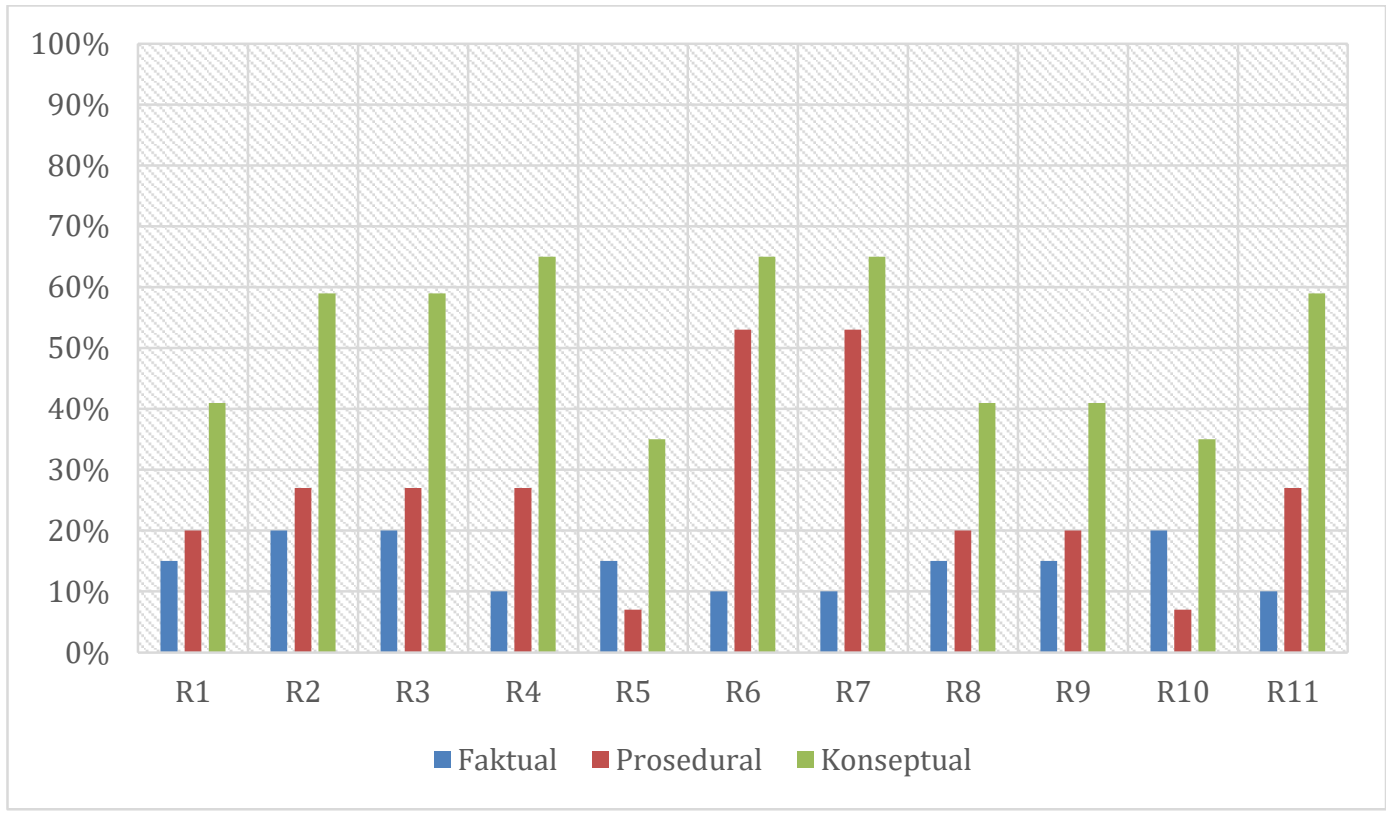

\section{Grafik 4 Persentase Kesalahan per Responden Berdasarkan Jenis Kesalahan}

Berdasarkan pemaparan hasil penelitian, diperoleh bahwa kesalahan secara umum dalam mengerjakan soal Aljabar Sederhana mencapai persentase 30,26\%. Besar persentase ini masih tergolong rendah. Dilihat dari butir soalnya, dari 20 butir soal yang 
diberikan, hanya 2 butir soal dijawab benar tanpa kesalahan oleh mahasiswa. Butir soal yang menghasilkan persentase kesalahan terbesar yang dilakukan oleh mahasiswa adalah nomor 6a (52\%) dengan kategori sedang. Dilihat dari respondennya, dari 11 orang mahasiswa, besar kesalahan merentang pada kisaran $16 \%-43 \%$.

Dalam penelitian ini membahas mengenai jenis kesalahan menjadi 3 (tiga), yaitu kesalahan faktual, kesalahan prosedural, dan kesalahan konseptual. Dilihat dari kesalahan faktual yang dilakukan pada semua butir soal, diperoleh kesalahan terbesar $100 \%$ pada soal 1c. Ditemukan bahwa ada mahasiswa yang salah menjawab variabel dan ada yang salah menjawab koefisien. Padahal variabel hanya $x$ dan $y$, dan koefisien dari suku kedua adalah -3, bukan 3. Semua responden salah menjawab kedua fakta tersebut. Sesuai dengan temuan dari Karlina, Masi, \& Kodirun, 2018), bahwa kesalahan fakta dapat terjadi ketika siswa kurang teliti dalam menyelesaikan soal dan tidak memperhatikan kembali jawaban yang sudah dikerjakan. Selain itu, temuan (Nurhamsiah, 2015) juga relevan bahwa siswa tidak mengetahui bahwa koefisien ada yang bernilai negatif.

Dilihat dari kesalahan prosedural yang dilakukan pada semua butir soal, diperoleh kesalahan terbesar $82 \%$ pada soal 9d. Pada soal 9d tersebut, ditemukan bahwa prosedur yang dilakukan mahasiswa tidak tidak tepat pada penyelesaian pertidaksamaan ganda. Soal 9d meminta mahasiswa untuk menyelesaikan pertidaksamaan $-3<2 x+5 \leq 17$ dengan $x \in \mathbb{R}$ dan gambarkan grafiknya. Persentase $82 \%$ menunjukkan bahwa mahasiswa tidak paham prosedur penyelesaian pertidaksamaan ganda. Hanya 2 (dua) orang responden atau sebesar 28\% responden yang melakukan prosedur dengan tepat. Mahasiswa dapat mengerjakan langsung dengan dua tanda pertidaksamaan atau dengan memecah-mecah menjadi 2 pertidaksamaan yang kemudian ditemukan himpunan penyelesaian yang beririsan.

Responden lainnya hanya mengerjakan sebagian prosedur yang tepat, namun tidak mengantarkan pada jawaban benar. Apabila pertidaksamaan ganda ingin diselesaikan dengan cara langsung, maka sifat-sifat pertidaksamaan harus berlaku pada setiap ruas. Ini mengindikasikan mahasiswa belum jelas dalam melakukan prosedur. Hal ini serupa dengan temuan Anjeli \& Irwan (2019) bahwa bentuk kesalahan prosedur yang dilakukan peserta didik adalah berupa tidak jelasnya metode apa yang digunakan peserta didik dalam menyelesaikan masalah yang diberikan. Anjeli \& Irwan (2019) juga memperoleh temuan bahwa penyebab terjadinya kesalahan prosedur tidak tepat yaitu 
peserta didik tidak menguasai meteri pembelajaran dan peserta didik tidak mengulang kembali pelajaran di rumah.

Dilihat dari kesalahan konseptual yang dilakukan pada semua butir soal, diperoleh kesalahan terbesar 100\% pada soal 8, 9a, 9b, 9c, 9d, dan 9e. Pada soal 8, responden salah menyatakan variabel $x$ sebagai harga $1 \mathrm{~kg}$ gula pasir. Semua responden hanya menyatakan $x$ sebagai hal yang tidak penuh, misalnya $x$ adalah gula pasir, atau 1 kg gula pasir. Hal ini menunjukkan adanya kesalahan pada ide mendasar. Ini juga menunjukkan bahwa memodelkan konsep variabel pada persamaan linear tidak dipahami dengan baik oleh mahasiswa, karena kemungkinan hanya fokus pada perhitungan.

Soal 8 adalah soal cerita sederhana yang seharusnya dapat lebih dicermati oleh mahasiswa, mulai dari apa yang diketahui, apa yang ditanya, dan bagaimana model matematikanya untuk menyelesaikan masalah tersebut. Menurut Sulastri \& Arhasy (2017), untuk menyelesaikan soal pemecahan masalah terkait konsep persamaan linear satu variabel (PLSV) responden harus terlebih dahulu membuat model matematika dari soal tersebut. Namun, bagaimana memodelkan matematika yang tepat mungkin bukan menjadi hal yang begitu penting sehingga menjadi kesalahan konseptual. Seperti temuan Sulastri \& Arhasy (2017), bahwa mayoritas peserta didik dapat menyelesaikan soal pemecahan masalah namun dengan tidak menghubungkan soal dengan konsep persamaan dan pertidaksamaan linear satu variabel. Jika hal ini terus berlanjut kedepannya peserta didik akan kesulitan dalam menyelesaikan soal-soal pemecahan masalah yang harus di selesaikan dengan konsep persamaan dan pertidaksamaan linear satu variabel (Sulastri \& Arhasy, 2017).

Pada soal 9a, 9b, 9c, 9d, dan 9e, permintaan dari soal adalah sama, yaitu mahasiswa diminta untuk menyelesaikan pertidaksamaannya dan menggambarkan daerah himpunan penyelesaian untuk $x$ adalah bilangan riil $(x \in \mathbb{R})$. Dari kelima soal tersebut, hanya ada 4 orang responden yang menyertakan gambar daerah himpunan penyelesaian. Namun itu pun tidak digambar dengan tepat. Gambar dari responden tidak menunjukkan adanya interval terbuka dan interval tertutup sesuai pertidaksamaan yang dimaksud. Misalnya tanda pertidaksamaan "<" dan tanda pertidaksamaan " $\leq$ " berbeda ketika digambarkan, biasanya digambarkan dengan bulatan berlubang $(\circ)$ dan bulatan tidak berlubang $(\bullet)$. Responden menggambarkannya tanpa membedakan kedua tanda itu dan digunakan secara bebas. Sedangkan 7 
responden lainnya tidak menggambar. Ini menunjukkan bahwa mahasiswa tidak memahami gambar daerah himpunan penyelesaian. Contoh pekerjaan responden dapat dilihat pada Gambar 4.10, 4.11, 4.12, 4.13, dan 4.14 yang telah dibahas sebelumnya.

Selain itu, contoh kesalahan pada konsep yang dilakukan mahasiswa seperti terlihat pada soal $6 \mathrm{a}$ dan $6 \mathrm{~b}$. Soal $6 \mathrm{a}$ dan $6 \mathrm{~b}$ adalah soal yang membutuhkan pengetahuan konseptual, tidak memerlukan pengetahuan prosedural. Mahasiswa diminta untuk memfaktorkan ekspresi aljabar $2 p q$. Jawaban yang benar adalah 1, 2, p, $2 p, q, 2 q, p q$, dan $2 p q$. Apabila mahasiswa tidak menjawab seperti itu maka konsep yang diterima mahasiswa masih keliru. Hanya 2 orang responden yang menjawab benar. Sedangkan 9 responden lainnya tidak menjawab dengan benar.

Hasil penelitian menunjukkan bahwa kesalahan faktual berkisar antara 10\% - 20\% (kategori Sangat Rendah), kesalahan prosedural berkisar antara 7\% - 53\% (kategori Sangat Rendah s.d. kategori Sedang), dan kesalahan konseptual berkisar antara 35\% 65\% (kategori Rendah s.d. kategori Tinggi). Ini berarti bahwa ternyata kesalahan konsep menduduki tingkat kesalahan tertinggi. Hal ini sesuai dengan pendapat Ginsburg (1987, dalam Lai, 2012) yang menyatakan bahwa kesalahan konseptual adalah kesalahan yang lebih serius. Menurut Andriani, Suastika, \& Sesanti (2017), matematika selalu identik dengan konsep dan siswa akan selalu dituntut untuk memahami konsep-konsep yang ada pada matematika. Andriani, Suastika, \& Sesanti (2017) juga menemukan bahwa siswa lebih sering mengerjakan soal tanpa menuliskan konsep yang digunakan. Penyebabnya karena memang siswa sudah terbiasa mengerjakan secara instan tanpa menuliskan prosedurnya secara lengkap.

\section{Kesimpulan}

Berdasarkan hasil dan pembahasan di atas, maka dapat disimpulkan beberapa hal sebagai berikut.

1. Tingkat kesalahan secara umum mahasiswa program studi PGSD pada tugas materi Aljabar Sederhana mata kuliah Konsep Dasar Mapel Matematika SD adalah sebesar $30,26 \%$. Ini berarti tingkat kesalahan mahasiswa secara umum berada pada kategori kesalahan rendah. Terdapat kesalahan tertinggi sebesar 43\% (kategori kesalahan sedang) dan terendah $16 \%$ (kategori kesalahan sangat rendah).

2. Dalam penelitian ini membedakan jenis kesalahan menjadi tiga, yaitu kesalahan, kesalahan prosedural, dan kesalahan konseptual. Kesalahan faktual berkisar antara 
10\% - 20\% (kategori Sangat Rendah). Kesalahan prosedural berkisar antara 7\% - 53\% (kategori Sangat Rendah s.d. kategori Sedang). Dan kesalahan konseptual berkisar antara 35\% - 65\% (kategori Rendah s.d. kategori Tinggi).

\section{Daftar Pustaka}

Anderson, L.W., \& Krathwohl, D.R. (2015). Kerangka Landasan Untuk Pembelajaran, Pengajaran, dan Asesmen Revisi Taksonomi Pendidikan Bloom. Terjemahan: Agung Prihantoro. Yogyakarta: Pustaka Belajar.

Andriani, T., Suastika, I., \& Sesanti, N. (2017). Analisis Kesalahan Konsep Matematika Siswa dalam Menyelesaikan Soal Trigonometri Kelas X TKJ SMKN 1 Gempol Tahun Pelajaran 2016/2017. Pi: Mathematics Education Journal, 1(1), 34-39. DOI: https:// doi.org/10.21067/pmej.v1i1.1998.

Anjeli, R., \& Irwan. (2019). Analisis Kesalahan Peserta Didik dalam Menyelesaikan Soal Cerita Berdasarkan Kriteria Watson. Jurnal Edukasi dan Penelitian Matematika, 8(1), 103-109.

Bethany. (2016). 3 Types of Math Errors and How to Prevent Them. Tersedia di https://mathgeekmama.com (diakses pada 22 Februari 2020).

Brown, J., Skow, K., \& The IRIS Center. (2016). Mathematics: Identifying and Addressing $\begin{array}{llll}\text { Student } & \text { Errors. } & \text { Tersedia }\end{array}$ http://iris.peabody.vanderbilt.edu/case_studies/ics_matherr.pdf (diakses pada 22 Februari 2020).

Dawkins, P. (2018). Common Math Errors. Tersedia di https://tutorial.math.lamar.edu/pdf/Common_Math_Errors.pdf (diakses pada 22 Februari 2020).

Karlina, K., Masi, L., \& Kodirun. (2018). Analisis Kesalahan dalam Menyelesaikan SoalSoal Bentuk Persamaan dan Pertidaksamaan Linear Satu Variabel pada Siswa Kelas VII SMP Negeri 2 Kendari. Jurnal Pendidikan Matematika, 6(2).

Lai, C. F. (2012). Error Analysis in Mathematics. Behavioral Research and Teaching. Tersedia di https://files.eric.ed.gov/fulltext/ED572252.pdf (diakses pada 22 Februari 2020)

Lestian, H. N., Rejeki, S., Setyawan, F. (2016). Identifying Students' Errors on Fractions. Journal of Research and Advances in Mathematics Education, 1(2), 131-139. ISSN: 25033697 / e-ISSN: 2541-2590 
Malihatuddarojah, D., \& Prahmana, R. C. I. (2019). Analisis Kesalahan Siswa Dalam Menyelesaikan Permasalahan Operasi Bentuk Aljabar. Jurnal Pendidikan Matematika, 13(1), 1-8. ISSN 1978-0044, E-ISSN 2549-1040

Nurhamsiah. (2015). Analisis Kesulitan Siswa dalam Mempelajari Bentuk Aljabar Berkaitan dengan Konsep dan Prinsip di SMP. Artikel Penelitian. Tersedia di https://media.neliti.com/media/publications/216247-analisis-kesulitan-siswadalam-mempelaja.pdf (diakses pada tanggal 15 Mei 2020)

Riccomini, P. J. (2016). How to Use Math Error Analysis to Improve Instruction. Tersedia di https://files.ernweb.com/erroranalysis.pdf (diakses pada 22 Februari 2020)

Sanwidi, A. (2018). Analisisi Kesalahan Mahasiswa Matematika UNU Blitar Dalam Menyelesaikan Soal Matematika Materi Fungsi Berdasarkan Kriteria Watson. BRILIANT: Jurnal Riset dan Konseptual, 3 (1), 128-132.

Sulastri, L., \& Arhasy, E., A., R. (2017). Kajian Learning Obstacle Materi Persamaan dan Pertidaksamaan Linear Satu Variabel pada Pembelajaran Matematika di Sekolah Menengah Pertama. Jurnal Penelitian Pendidikan dan Pengajaran Matematika, 3(2), 151-159.

Van de Walle, J. A., Karp, K. S., \& Bay-Williams, J.M. (2013). Elementary and Middle School Mathematics: Teaching Developmentally (8th Edition). USA: Pearson Education, Inc. 